\title{
Proteomics analysis identifies PARK7 as an important player for renal cell resistance and survival under oxidative stress
}

\author{
Marwa Eltoweissy, ${ }^{a}$ Gerhard A. Müller, ${ }^{a}$ Asima Bibi, ${ }^{a}$ Phuc Van Nguye, ${ }^{a}$ \\ Gry H. Dihazi, ${ }^{a}$ Claudia A. Müller ${ }^{b}$ and Hassan Dihazi ${ }^{a} a$
}

Received 26th July 2010, Accepted 18th January 2011

DOI: $10.1039 / \mathrm{comb00116c}$

Renal fibrosis is a process that is characterized by declining excretory renal function.

The molecular mechanisms of fibrosis are not fully understood. Oxidative stress pathways were reported to be involved in renal tissue deterioration and fibrosis progression. In order to identify new molecular targets associated with oxidative stress and renal fibrosis, differential proteomics analysis was performed with established renal cell lines (TK173 and HK-2). The cells were treated with oxidative stress triggering factor $\mathrm{H}_{2} \mathrm{O}_{2}$ and the proteome alterations were investigated. Two dimensional protein maps were generated and differentially expressed proteins were processed and identified using mass spectrometry analysis combined with data base search. Interestingly the increase of ROS in the renal cell lines upon $\mathrm{H}_{2} \mathrm{O}_{2}$ treatment was accompanied by alteration of a large number of proteins, which could be classified in three categories: the first category grouped the proteins that have been described to be involved in fibrogenesis (e.g. ACTA2, VIN, VIM, DES, KRT, COL1A1, COL4A1), the second category, which was more interesting involved proteins of the oxidative stress pathway (PRDX1, PRDX2, PRDX6, SOD, PARK7, HYOU1), which were highly up-regulated under oxidative stress, and the third category represented proteins, which are involved in different other metabolic pathways. Among the oxidative stress proteins the up-regulation of PARK7 was accompanied by a shift in the $\mathrm{pI}$ as a result of oxidation. Knockdown of PARK7 using siRNA led to significant reduction in renal cell viability under oxidative stress. Under $\mathrm{H}_{2} \mathrm{O}_{2}$ treatment the PARK7 knockdown cells showed up to $80 \%$ decrease in cell viability and an increase in apoptosis compared to the controls. These results highlight for the first time the important role of PARK7 in oxidative stress resistance in renal cells.

\section{Introduction}

Organisms and cells undergo a variety of molecular and physiological changes resulting from their interaction with the environment. Respiration or exposure to external agents (e.g. light, ionizing radiation or some redox drugs) may result in a partial reduction of cellular oxygen leading to serious imbalance between the production of free radicals and the antioxidant defense. Such a situation generates a diverse group of reactive species known collectively as "reactive oxygen species" (ROS). ${ }^{1}$ The production of ROS, in turn, leads to the formation of a broad variety of other modified and

${ }^{a}$ Department of Nephrology and Rheumatology, University Medical Center Goettingen, Georg-August University Goettingen,

Robert-Koch-Strasse 40, D-37075 Goettingen, Germany.

E-mail: dihazi@med.uni-goettingen.de; Fax: +049-551-3991039;

Tel: +049-551-3991221

${ }^{b}$ Section for Transplantation-Immunology and Immunohematology,

ZMF, University Tuebingen, Waldhörnle Str. 22 Germany oxidized cellular molecules resulting in a state of oxidative stress. Despite the diverse number of cellular defenses and pathways to counteract the negative effects, excessive ROS production beyond the organ's scavenging capacity simultaneously attacks and alters other target molecules and causes lipid peroxidation induction, DNA breakdown and/or proteins denaturation. ${ }^{2}$

A growing body of evidence suggests oxidative stress as one of the most relevant pathogenic influences in numerous human diseases, including diabetes, vascular complications, ${ }^{3}$ cancer, ${ }^{4}$ and neurodegenerative disorders such as Alzheimer's ${ }^{5}$ and Parkinson's disease. ${ }^{6}$ Oxidative stress has also been reported in association with the occurrence of impaired reproductive function, ${ }^{7}$ and as a major cause of liver damage, ${ }^{8}$ and cardiac myocyte death. ${ }^{9}$ Oxidative stress also plays a fundamental role in cataractogenesis, ${ }^{10}$ it contributes to mucosal inflammation of the gastrointestinal tract ${ }^{11}$ and is important in aging processes. ${ }^{12}$ There is convincing experimental and clinical evidence that ROS generation is an important fibrogenic 
factor and that most, if not all, progressive renal diseases are the consequence of a deleterious process of destructive interstitial fibrosis. $^{12}$

The molecular pathogenesis of renal interstitial fibrosis correlates with the degree of renal functional loss and predicts the rate of progression to end-stage renal failure. ${ }^{13}$

Different players were described to be involved in the antioxidant response of the cells. ${ }^{14-17}$ Among the antioxidant agents PARK7 is a redox-responsive cytoprotective protein with diverse functions. It was first identified as an oncogene that transformed cells. ${ }^{18}$ Functional studies showed that PARK7 may become activated in the presence of ROS, produced under conditions of oxidative stress, but also as a part of physiological receptor-mediated signal transduction. As an important regulator of redox signaling kinase pathways, PARK7 can act as a transcriptional modulator of antioxidative gene expression. Activation of PARK7 leads to a shift of the protein to more acidic (oxidized) forms in Parkinson's disease. ${ }^{19}$ Thus, PARK 7 oxidized modifications are specifically linked to diseases.

ROS are generated through normal cellular processes in aerobic organisms. Besides the normal singlet oxygen, the ROS include the products which are generated during reduction of oxygen to water: superoxide anion $\left(\mathrm{O}_{2}{ }^{\bullet-}\right)$, hydrogen peroxide $\left(\mathrm{H}_{2} \mathrm{O}_{2}\right)$, and hydroxyl radical $\left(\mathrm{OH}^{\bullet}\right)$. Hydrogen peroxide $\left(\mathrm{H}_{2} \mathrm{O}_{2}\right)$ can rapidly be converted into highly oxidizing hydroxyl radicals $\left(\mathrm{OH}^{\bullet}\right)$ and generate oxidative stress by overwhelming the intracellular antioxidant mechanisms thus, modulating intracellular signaling pathways, including apoptosis and cell cycle regulation. ${ }^{20}$ While several markers of chronic oxidative stress induced by $\mathrm{H}_{2} \mathrm{O}_{2}$ are well known, evidence for the regulatory mechanisms underlying oxidative renal injury at the proteome level are still lacking. The current work has therefore been designed to define molecular pathways linking $\mathrm{H}_{2} \mathrm{O}_{2}$ induced oxidative stress to cellular dysfunction through proteomic analysis. Using this methodology, it may not only be possible to provide a basic theory and new opportunities for elucidating significant mechanisms by recognizing changes of global protein expression profiles, but will further yield a quantitative evaluation on the expression level of cellular proteins, thus helping in the identification of new diagnostic markers. To achieve this goal, experiments have been conducted using a well-established and characterized renal fibroblast (TK173) and tubular epithelial cell line (HK2) as model systems and potential cellular key-players in renal fibrosis.

\section{Materials and methods}

\section{Cell line and culture procedure}

The human renal fibroblast cell line (TK 173) used in these experiments was derived from a normal human kidney biopsy. The renal cells were immortalized by transfection with the plasmid pSV3gpt which encodes the large $\mathrm{T}$ antigen from SV40 and have typical morphological and biochemical properties of renal interstitial fibroblasts. ${ }^{21}$

The TK173 cell line was routinely maintained in $75 \mathrm{~cm}^{2}$ tissue culture flasks (Falcon) in Dulbecco's modified Eagle's medium (Gibco) supplemented with 10\% fetal calf serum (FCS, Gibco), 1\% L-glutamine (PAA) and 1\% penicillin/ streptomycin (PAA). A renal epithelial cell line designated HK-2 (human kidney-2) also used in these experiments was derived from normal adult human renal cortex. ${ }^{22}$ Cultured cells were exposed to a recombinant retrovirus containing the HPV 16 E6/E7 genes. They show a high degree of differentiation and specialization in vitro and provide a suitable model to study the function of renal proximal tubular epithelials in vitro. The HK-2 cell line was maintained as a monolayer culture in Quantum 286 medium for epithelial cells (PAA) with $1 \%$ penicillin/streptomycin (Gibco). Cells were regularly passaged at $85-90 \%$ confluency. Before the start of each experiment, normal growing cells were harvested with trypsin, recultured in $7 \mathrm{ml}$ medium at a density of $5 \times 10^{4}$ cells per flask and allowed to attach and grow overnight at $37{ }^{\circ} \mathrm{C}$ in a humidified atmosphere of $5 \% \mathrm{CO}_{2}$ and $95 \%$ air.

\section{Cell viability assay}

The Cell Proliferation Kit I (Roche), a colourimetric assay, was used for the non-radioactive quantification of cell proliferation and viability (Roche Applied Science, Mannheim, Germany). The assay is based on the cleavage of the yellow tetra-zolium salt 3-(4,5-dimethylthiazol-2-yl)-2,5 diphenyltetrazolium bromide (MTT) to purple formazan crystals by metabolic active cells. ${ }^{23}$ The formazan crystals formed are solubilized and the resulting colored solution is quantified using a plate reader. Cells were plated in $200 \mu \mathrm{l}$ of medium at a concentration of $5 \times 10^{3}$ cells per flat-bottomed well in 96-well plates (tissue culture grade, Falcon). After overnight incubation, the medium was replaced with standard media containing different hydrogen peroxide $\left(\mathrm{H}_{2} \mathrm{O}_{2}\right)$ (Merck) concentrations ranging from 0 to $1000 \mu \mathrm{M}$ for induction of viability changes, the cells were then re-incubated for $24 \mathrm{~h}$. After this incubation period, $10 \mu \mathrm{l}$ of the MTT labeling reagent $\left(0.5 \mathrm{mg} \mathrm{ml}^{-1}\right)$ were added to each well and the 96-well plates were again incubated for $4 \mathrm{~h}$. After the addition of $100 \mu \mathrm{l}$ of the solubilization solution into each well the plates were kept overnight in the incubator. Thereafter the cell viability was quantified using a plate reader by light absorbance at a wavelength between $550-600 \mathrm{~nm}$ with a reference wavelength $>650 \mathrm{~nm}$. Standard curves correlating the absorbance to the cell number were established and used to quantify cell number changes in test wells. For $72 \mathrm{~h}$ cell viability experiments, test media were changed every day before undergoing further steps of analysis.

\section{Oxidative stress induction}

To mimic oxidative stress conditions, cells prepared in culture flasks at a concentration of $5 \times 10^{3}$ cells per flask were allowed to grow overnight and were then treated with culture medium containing $200 \mu \mathrm{M} \mathrm{H}_{2} \mathrm{O}_{2}$ (maximum concentration was chosen according to the cell viability experiments). This medium was replaced with a freshly prepared stress medium every $24 \mathrm{~h}$ throughout a $72 \mathrm{~h}$ experimental period. For each experiment, a control group was handled in parallel to the treated culture group under similar experimental conditions with the exception 
that the culture medium contained no $\mathrm{H}_{2} \mathrm{O}_{2}$ additive. All oxidative stress experiments were repeated three times.

\section{Detection of reactive oxygen species (ROS) production}

The fibroblast cell line TK173 cells were grown to confluence in 96-well cell culture plates. Cells in several test wells were then stimulated with $200 \mu \mathrm{M} \mathrm{H}_{2} \mathrm{O}_{2}$ for $2 \mathrm{~h}$ in comparison to untreated control wells. Dihydrorhodamine-123 (DHR-123, Sigma) stock $(10 \mu \mathrm{M})$ solution was made in DMSO, and stored at $-20{ }^{\circ} \mathrm{C}$. Oxidative stress as manifested by ROS production was assessed by preloading the cells, both the control and the $\mathrm{H}_{2} \mathrm{O}_{2}$ treated wells with $50 \mu \mathrm{M}$ DHR-123 and incubated at $37{ }^{\circ} \mathrm{C}$ for $30 \mathrm{~min}$. Intracellular DHR-123 oxidation was imaged using a fluorescence microscope (Zeiss) and appropriate filters. ${ }^{24}$

\section{Cell lysis and protein extraction}

At the end of each experiment, $75 \%$ confluent cell culture flaks were scraped and cells were rinsed twice with phosphatebuffered saline (PBS, Gibco). After centrifugation at $1100 \mathrm{rpm}$ for $5 \mathrm{~min}$ at $4{ }^{\circ} \mathrm{C}$ the supernatant was removed and the cell pellets were treated with $0.3-0.5 \mathrm{ml}$ of lysis buffer containing 9.5 M urea (Sigma), 2\% (w/v) CHAPS (Merck), 2\% (w/v) ampholytes, 1\% DTT (Sigma), and $10 \mathrm{mM}$ PMSF. Aliquots of $500 \mu \mathrm{l}$ of urea buffer were frozen until use. Ampholytes, DTT, pepstatin (to a final concentration of $1.4 \mu \mathrm{M}$ ), and Complete $^{\mathrm{TM}}$ from Roche Diagnostic (according to the manufacturer's protocol) were freshly added. After adding the lysis buffer the samples were incubated for $30 \mathrm{~min}$ at $4{ }^{\circ} \mathrm{C}$. For removing the cell debris, sample centrifugation was carried out at $14000 \mathrm{rpm}$ and $4{ }^{\circ} \mathrm{C}$ for $30 \mathrm{~min}$. The supernatant was centrifuged at $14000 \mathrm{rpm}$ at $4{ }^{\circ} \mathrm{C}$ for an additional $30 \mathrm{~min}$ to get maximal purity. The resulting samples were used immediately or stored at $-20{ }^{\circ} \mathrm{C}$ until used. Protein concentration was determined according to Bradford ${ }^{25}$ using bovine serum albumin (Roche Applied Science) as a standard.

\section{Two-dimensional gel electrophoresis (2-DE)}

Each sample was diluted in rehydration buffer (8 M urea, $1 \%(\mathrm{w} / \mathrm{v})$ CHAPS, $0.2 \%$ ampholytes $\mathrm{pH} 3-10,1 \%$ DTT, and a trace of bromophenol blue) to a final volume of $175 \mu$. The mixture containing $150 \mu \mathrm{g}$ of proteins from cell lysate was used

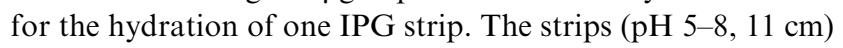
were allowed to rehydrate for $30 \mathrm{~min}$ before adding mineral oil (Bio-Rad). The passive rehydration of the strips was carried out overnight for at least $12 \mathrm{~h}$ at room temperature in a focusing chamber. Isoelectric focusing was performed on the PROTEAN IEF Cell (Bio-Rad) at a controlled temperature of $20{ }^{\circ} \mathrm{C}$ using the following multistep voltage setting protocol: $500 \mathrm{~V}$ for $1 \mathrm{~h}, 1000 \mathrm{~V}$ for $1 \mathrm{~h}, 2000 \mathrm{~V}$ for $1 \mathrm{~h}$ and left at $8000 \mathrm{~V}$ until a total of $50000 \mathrm{Vh}$ was reached. After the first dimension, the individual strips were equilibrated at room temperature in SDS equilibration buffer containing $6 \mathrm{M}$ urea, $30 \%$ (w/v) glycerol, 2\% SDS (w/v), $0.05 \mathrm{M}$ Tris- $\mathrm{HCl}(\mathrm{pH} 8.8)$, $2 \%$ DTT and a trace of bromophenol blue for $20 \mathrm{~min}$. An additional incubation in the same buffer supplemented with iodoacetamide $(2.5 \%)$ instead of DTT was subsequently carried out for another $20 \mathrm{~min}$. The second dimension was performed using SDS-PAGE, 12\% BisTris Criterion precast gels (Bio-Rad) according to the manufacturer's instructions. The gels were run at $150 \mathrm{~V}$ for $10 \mathrm{~min}$ followed by $200 \mathrm{~V}$ until the bromophenol blue front had reached the bottom of the gel.

\section{Gel staining}

For image analysis, 2-DE gels were fixed overnight in a solution containing $50 \%$ methanol and $12 \%$ acetic acid. Gels were then stained with Flamingo fluorescent stain (Bio-Rad) for at least $5 \mathrm{~h}$. After staining, gels were scanned at $50 \mu \mathrm{m}$ resolution on a Fuji FLA5100 scanner. The digitalized images were analyzed using Delta 2D 3.4 (Decodon, Germany). For protein spot visualization, the 2-DE gels were post-stained with colloidal Coomassie (Roti-Blue, Roth, Germany) overnight, thus enabling manual spot excision for trypsin digestion and mass spectrometry analysis for protein identification.

In-gel digestion and mass spectrometry analysis of protein spots

Manually excised protein spots from the gels were washed with distilled water for $15 \mathrm{~min}$. The destaining procedure was carried out by washing the spots alternately with $50 \%$ acetonitrile (ACN) and $100 \mathrm{mM}$ ammonium bicarbonate three times for $5 \mathrm{~min}$. After dehydrating the spots with $100 \%$ ACN for $15 \mathrm{~min}$, they were dried in a vacuum centrifuge for $\sim 15 \mathrm{~min}$. Thereafter, the gel spots were rehydrated for digestion with $20 \mu \mathrm{l}$ of trypsin $\left(10 \mathrm{ng} \mu \mathrm{l}^{-1}\right.$ in $100 \mathrm{mM}$ ammonium bicarbonate) and incubated at $37{ }^{\circ} \mathrm{C}$ overnight. The extraction of the peptide sample was carried out with different concentrations of ACN and trifluoroacetic acid (TFA) under sonication. All supernatants were pooled together, dried in a vacuum centrifuge, and dissolved in $0.3 \%$ TFA. The mass spectrometry analysis and protein identification were performed as described previously. ${ }^{26}$

\section{Western blot analysis}

Proteins $(40 \mu \mathrm{g})$ were separated by SDS-PAGE and transferred to a Hybond ECL nitrocellulose membrane (GE Healthcare). Immunodetection was performed according to Towbin et al. ${ }^{27}$ Briefly, membranes were blocked in $5 \%$ milk for $2 \mathrm{~h}$ at room temperature, followed by overnight incubation at $4{ }^{\circ} \mathrm{C}$ with diluted specific primary antibody. Rabbit monoclonal anti-PARK7 (1:1000), rabbit polyclonal anti-fibronectin (1: 5000), mouse monoclonal anti-vinculin (1:500) antibodies (Sigma), rabbit polyclonal anti-superoxide dismutase 1 (1 : 2000) antibody (Abnova), rabbit monoclonal anti-peroxiredoxine 6 (1: 2000) antibody (Abcam), mouse monoclonal anti-vimentin ( $1: 5000)$ antibody (Dako) and mouse monoclonal anti- $\beta$-actin ( $1: 5000)$ were used as primary antibodies. Molecular Probes Alexa Fluor 647 goat anti-mouse IgG antibody or Alexa Fluor 647 goat anti-rabbit $\operatorname{IgG}(1: 2000)$ were used as secondary antibodies. Before imaging, the blots were dried in the dark. The blot membranes were scanned at $50 \mu \mathrm{m}$ resolution on a Fuji FLA5100 scanner (Fuji Photo) with single laser-emitting excitation light at $635 \mathrm{~nm}$.

\section{Bioinformatics}

The identified protein list was submitted according to their official gene symbol (listed in Table 1) to DAVID bioinformatics 
Table 1 Identification of the proteins found to be differentially regulated upon oxidative stress. The name, gene name, SwissProt accession number, molecular weight, ESI MS/MS score and the sequence coverage are given

\begin{tabular}{|c|c|c|c|c|c|c|}
\hline & Protein name & Gene name & Swiss-prot accession nr. & MW & ESI MS/MS score & Sequence coverage \\
\hline 1 & Protein DJ-1, Parkinson's disease protein 7 & PARK7 & Q99497 & 20050 & 166 & 22 \\
\hline 2 & Superoxide dismutase $[\mathrm{Cu}-\mathrm{Zn}]$ & SOD 1 & P00441 & 16154 & 80 & 11 \\
\hline 3 & Peroxiredoxin-2 & PRDX2 & P32119 & 22049 & 188 & 24 \\
\hline 4 & Ubiquitin carboxyl-terminal hydrolase isozyme L1 & UCHL1 & P09936 & 25151 & 166 & 18 \\
\hline 5 & Eukaryotic translation initiation factor $5 \mathrm{~A}-1$ & EIF5A & P63241 & 17049 & 71 & 9 \\
\hline 6 & Enhancer of rudimentary homolog & ERH & P84090 & 12422 & 74 & 10 \\
\hline 7 & Thioredoxin & TXN & P10599 & 12015 & 59 & 8 \\
\hline 8 & Rho GDP-dissociation inhibitor 1 & GDIA1 & P52565 & 23250 & 110 & 17 \\
\hline 9 & Calpain small subunit 1 & CAPNS 1 & P04632 & 28469 & 60 & 11 \\
\hline 10 & Rho GDP-dissociation inhibitor 2 & GDIA2 & P52566 & 23031 & 72 & 12 \\
\hline 11 & Ubiquitin & UBC & P62988 & 8560 & 81 & 14 \\
\hline 12 & $4 \mathrm{OS}$ ribosomal protein $\mathrm{S} 12$ & RPS12 & P25398 & 14859 & 74 & 13 \\
\hline 13 & UPF0556protein $\mathrm{C} 19$ or $\mathrm{f} 10$ & $\mathrm{C} 19$ or $\mathrm{f} 10$ & Q969H8 & 18897 & 78 & 13 \\
\hline 14 & Transcription factor BTF3 & BTF3 & P20290 & 22211 & 64 & 11 \\
\hline 15 & Confilin 1 & CFL1 & P23528 & 18719 & 110 & 20 \\
\hline 16 & Peroxiredoxin-6 & PRDX6 & P30041 & 22324 & 118 & 19 \\
\hline 17 & Triosephosphate isomerase & TP11 & P60174 & 26938 & 208 & 26 \\
\hline 18 & $S$-formylglutathione hydrolase & ESD & P10768 & 31956 & 82 & 7 \\
\hline 19 & Heterogeneous nuclear ribonucleoprotein $\mathrm{H} 3$ & HNRNPH3 & P31942 & 36960 & 111 & 15 \\
\hline 20 & Glyceraldehyde-3-phosphate dehydrogenase & GAPDH & P04406 & 36202 & 139 & 16 \\
\hline 21 & Annexin A2 & ANXA2 & P07355 & 38808 & 63 & 8 \\
\hline 22 & Calponin-2 & CNN2 & Q99439 & 34074 & 60 & 8 \\
\hline 23 & Actin, cytoplasmic 1 & ACTB & P60709 & 42052 & 117 & 14 \\
\hline 24 & Alpha-enolase & ENO1 & P06733 & 47481 & 182 & 23 \\
\hline 25 & Stress-induced-phosphoprotein 1 & STIP1 & P31948 & 63227 & 294 & 32 \\
\hline 26 & Far upstream element-binding protein 1 & FUBP1 & Q96AE4 & 67690 & 62 & 11 \\
\hline 27 & Stress-70 protein, mitochondrial & HSPA9 & P38646 & 73920 & 72 & 14 \\
\hline 28 & $78 \mathrm{kDa}$ glucose-regulated protein & HSPA5 & P11021 & 72402 & 192 & 24 \\
\hline 29 & Vimentin & VIM & P06870 & 53676 & 349 & 36 \\
\hline 30 & Vinculin & VCL & P18206 & 123591 & 231 & 32 \\
\hline 31 & Fibronectin & FN1 & P02751 & 262607 & 225 & 28 \\
\hline 32 & Collagen alpha-1(1) chain & COLIA1 & P02452 & 139853 & 102 & 22 \\
\hline
\end{tabular}

(www.david.abcc.ncifcrf.gov). By applying the gene ID conversion tool, all proteins were identified by DAVID ID. The new converted list was used to analyze and categorize the gene ontology ((GO)-annotations cellular components and molecular function). To limit annotations, Homo sapiens was chosen as the background.

\section{siRNA construct and transfection}

siRNA oligonucleotides specific for the knockdown of PARK7 expression (sense strand: 5'-ACCTCGAAGGCTCCACTGTTCTTAATCAAGAGTTAAGAACAAGTGGAGCСТTCTT-3'), (antisense strand: $3^{\prime}$-CAAAAAGAAGGCTCCACTTGTTCTTAACTCTTGATTAAGAAACAAGTGGAGCCTTCG-5'), were designed in our laboratory and synthesized by Eurofins MWG Operon. The siRNA vector was constructed by ligating oligonucleotides in the psiRNAh7SK neo vector (Invitrogen). All constructs were verified by sequencing. TK 173 and HK-2 cells cultured to approximately $80 \%$ confluence were transfected with the siRNA containing vector for the knockdown of PARK7 using the transfection reagent Lipofectamine $2000^{\mathrm{TM}}$ (Invitrogen) according to the standard protocol of the manufacturer, non-transfected cells and cells transfected with psiRNAh7SK empty plasmid only were kept as controls. After $24 \mathrm{~h}$ the transfection media were changed to normal culture media supplemented with $0.5 \mathrm{mg} \mathrm{ml}^{-1} \mathrm{G}-418$ (Invitrogen) as selection criteria for stable transfection. Cells were maintained in the selective medium for 14 days to achieve stable transfection. Cells were assessed for PARK7 expression by immunoblotting. The PARK7 knockdown cells were then subjected to oxidative stress for different times and the cell viability was assessed as described above.

\section{Statistical analysis}

All values are presented as mean $\pm \mathrm{SD}(n=3)$. Statistical analysis was performed with GraphPad Prism 4 software. Comparisons of two groups were conducted using paired two-tailed $t$-test. Statistical analyses among three or more groups were performed using one-way analysis of variance (ANOVA). Differences among groups were declared statistically significant if $p<0.05$.

\section{Results}

\section{Effects of oxidative stress on kidney fibroblast viability}

We attempted to assess the response of renal fibroblast cells stimulated with $\mathrm{H}_{2} \mathrm{O}_{2}$ over $24 \mathrm{~h}$ using the MTT cell viability assay. TK173 cells were initially seeded in 96-well plates and grown in normal cell culture medium. A group of cells were then stimulated with various concentrations of $\mathrm{H}_{2} \mathrm{O}_{2}$ $(50-1000 \mu \mathrm{M})$ and the percent viability was compared to control cultures after $24 \mathrm{~h}$. As shown in Fig. 1, cell survival was strongly correlated with the $\mathrm{H}_{2} \mathrm{O}_{2}$ concentration. No significant 


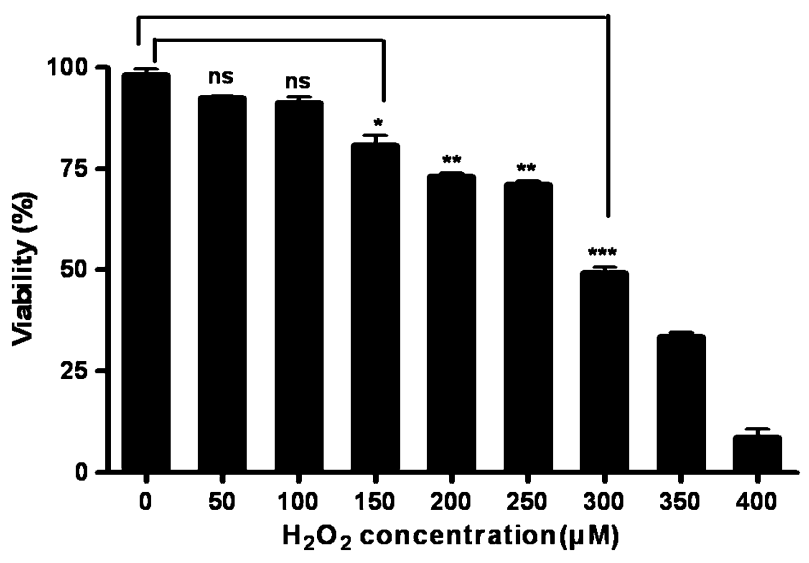

Fig. 1 MTT assay results showing cell viability under different $\mathrm{H}_{2} \mathrm{O}_{2}$ concentrations over $24 \mathrm{~h}$. Results are represented as a mean of 12 readings $\pm \mathrm{SD}$. Statistical analysis were performed using Graph Pad Prism 4 software and one way ANOVA test. Statistical significance was assumed for $p$-values $<0.05$ : ${ }^{*} P<0.05,{ }^{* *} P<0.01$, ${ }^{* * *} P<0.001$.

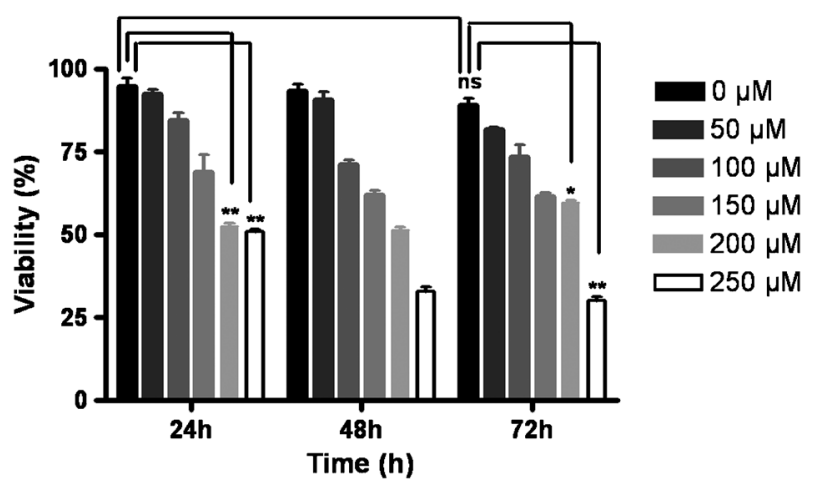

Fig. 2 MTT assay showing time dependent cell viability under different $\mathrm{H}_{2} \mathrm{O}_{2}$ concentrations over $72 \mathrm{~h}$. Results are represented as a mean of 12 readings $\pm \mathrm{SD}$. Statistical analysis were performed using Graphpad Pad Prism 4 software and one way ANOVA test. Statistical significance was assumed for $p$-values $<0.05$ : ${ }^{*} P<0.05$, $* * P<0.01$.

changes were observed between the control cells and with low $\mathrm{H}_{2} \mathrm{O}_{2}$ dose $(50-100 \mu \mathrm{M})$ treated cells. Cell death was more pronounced $(p<0.001)$ at $300 \mu \mathrm{M}$ of $\mathrm{H}_{2} \mathrm{O}_{2}$. Moreover, our first attempts showed that $\mathrm{H}_{2} \mathrm{O}_{2}$ concentrations of $600 \mu \mathrm{M}$ and higher led to direct cell apoptosis. These findings suggested that cells lost their ability to counteract oxidative stress induced by $\mathrm{H}_{2} \mathrm{O}_{2}$ at a concentration higher than $300 \mu \mathrm{M}$. Consequently, for optimal oxidative stress experimental conditions, incubation times of $72 \mathrm{~h}$ and $\mathrm{H}_{2} \mathrm{O}_{2}$ maximal concentration of $250 \mu \mathrm{M}$ were chosen. After overnight incubation at $37{ }^{\circ} \mathrm{C}$ in a $5 \% \mathrm{CO}_{2}$ incubator, the medium was replaced with $200 \mu$ of the standard medium, and various amounts of $10 \mathrm{mM} \mathrm{H}_{2} \mathrm{O}_{2}$ were added to achieve the required concentration. The medium change was performed every $24 \mathrm{~h}$ for both the treated cells and the control. Cell viability assay revealed that the stress effect of $\mathrm{H}_{2} \mathrm{O}_{2}$ was significant at $200 \mu \mathrm{M}$. Despite a pronounced death rate observed during the first $24 \mathrm{~h}$ of treatment (Fig. 2), cells showed partial recovery after $48 \mathrm{~h}$. After $72 \mathrm{~h}$ the cells seemed to develop resistance and grew with less significant difference in their growth rate compared to the controls $(P<0.05)$. In contrast, cells exposed to $250 \mu \mathrm{M} \mathrm{H}_{2} \mathrm{O}_{2}$ showed non-significant recovery after $48 \mathrm{~h}$, but proceeded with significant cell death after $72 \mathrm{~h}$. To counterbalance the negative effects of oxidative injury, the cells triggered a series of intracellular responses that could ultimately lead to protection against the stress stimulus. Using DHR-123, an uncharged, nonfluorescent agent that can be converted by oxidation to the fluorescent laser dye rhodamine 123, we confirmed that the treatment of renal cells with $200 \mu \mathrm{M} \mathrm{H} \mathrm{H}_{2} \mathrm{O}_{2}$ resulted in accumulation of hyperactive ROS derivatives as visualized by excess fluorescence intensity in the treated group of cells (Fig. 3A and B). DHR-123 is often used to detect the production of reactive nitrogen and oxygen species in cells via its oxidation into their respective fluorescent products. ROS e.g. peroxynitrite, hypochlorous acid, and $\mathrm{H}_{2} \mathrm{O}_{2}$ oxidize DHR-123 to varying degrees. Based on these results, we suggested that a treatment of the renal cells for $72 \mathrm{~h}$ with $200 \mu \mathrm{M} \mathrm{H} \mathrm{H}_{2} \mathrm{O}_{2}$ would provide a good system to study the impact of oxidative stress on cell proteome in renal cells. These incubation conditions were chosen because they allow an optimal time period for the cells to recover from oxidative stress.
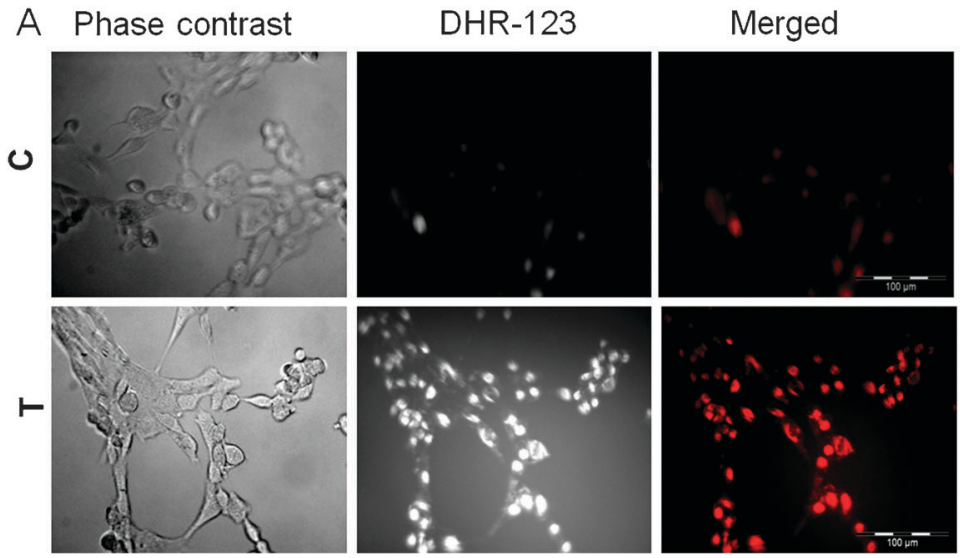

B

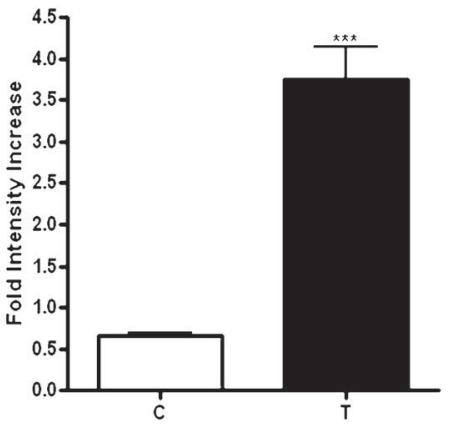

Fig. 3 Fluorescence microscopy comparing DHR-123 stained control and treated TK173 cells with $200 \mu \mathrm{M} \mathrm{H}_{2} \mathrm{O}_{2}$. Cells were stained with DHR-123 for 2 hours and visualized using specific filter sets for phase contrast and rhodamine. The obtained images were merged to observe cell morphology. Scale bar $=100 \mu \mathrm{m}$. 


\section{Impact of oxidative stress on renal cell protein pattern}

To detect and identify altered protein expression induced by $\mathrm{H}_{2} \mathrm{O}_{2}$ exposure, we employed conventional 2-DE coupled with mass spectrometry analysis. This approach allows the identification of novel proteins that have not been previously described to be implicated in the process of oxidative stress induced by $\mathrm{H}_{2} \mathrm{O}_{2}$ in renal fibroblasts and tubular epithelial cells. Simultaneously it offered the possibility to directly analyze the complex biological processes involved.

To establish gel-based reference maps allowing the investigation of the effects of $\mathrm{H}_{2} \mathrm{O}_{2}$ exposure on the renal cells proteome and meanwhile to ensure that results will not be influenced by spot mismatches, the 2-D gel images produced from three independent experiments for both the control and the treated groups were further overlapped using the DECODON software. Well-resolved, reproducible patterns of total protein expression profiles were obtained illustrating differentially expressed protein spots with high reproducibility. The comparison of the gels of the $\mathrm{H}_{2} \mathrm{O}_{2}$ treated cells with those of the control cells showed that $\mathrm{H}_{2} \mathrm{O}_{2}$ exerted toxic effects and altered proteins with higher expression and/or caused pI shifts. For mass spectrometry analysis, preparative 2D gels were stained with Coomassie brilliant blue to visualize all protein spots. Subsequently, differently expressed protein spots were cut out manually and digested for mass spectrometric analysis. In this report, we have restricted our list of proteins identified by mass spectrometry to those spots with MASCOT confidence interval scores of $>95 \%$.

Peptide mass fingerprint analysis and non-redundant sequence database matching allowed the identification of diverse groups of proteins. All of the identified proteins, which showed difference in expression under $\mathrm{H}_{2} \mathrm{O}_{2}$ treatment, are numbered and shown in Fig. 4. Spot numbers on 2-DE image matches are listed in Table 1 with further information about the identified protein.

\section{Bioinformatics analysis of the identified proteins}

Using gene ontology resources, such as the DAVID database, and conventional searches of the literature we were able to assign the identified proteins according to their molecular function (Fig. 5A) and cellular location (Fig. 5B) into different categories. Of particular interest, a major functional group responding to the stress stimulus consisted of $37.1 \%$ of the cellular proteins. Among them were various antioxidant proteins playing a role in the cell redox homeostasis (PRDX2, PRDX6), or in hydrogen peroxide biosynthetic processes (SOD1). Others are known to act as chaperones or chaperone binding proteins (PARK7, HSPA5, HSPA9, STIP1, SOD1). This diversity of proteins seems to be essential as a positive regulator and sensor for oxidative stress thus enhancing mechanisms that can generate ROS in the oxidative environment, where there are high oxygen levels and where host defense elements are constantly dealing with pathogenic and toxic threats. Moreover, anti-apoptosis functioning proteins (GDIA1, GDIA2, ACTB, CFL1, UBC, VIM, VCL, FN1, COL1A1) involved either in cell adhesion, in the attachment of the actin-based microfilaments to the plasma membrane, in binding cell surfaces with various compounds, in cell motility, opsonisation, locomotion, and/or maintenance of cell morphology were stimulated. The percentage of all molecular functions of the identified proteins is traced in a pie chart represented in Fig. 5A. These include cellular, metabolic, biological, developmental and multi-cellular processes, cellular component organization and cell death. It is noteworthy mentioning that a number of proteins are included in more than one group. These results support the view that the cellular adaptation to oxidative stress is accompanied by modulation of diverse cellular functions. Proteins involved in these cellular adaptations are also located according to their subcellular distribution analysis in a variety of compartments with the majority $(97.1 \%)$ being intracellular. The rest of the terms were intracellular organelle, membrane-bounded organelle, intracellular organelle part, non-membrane bounded organelle,

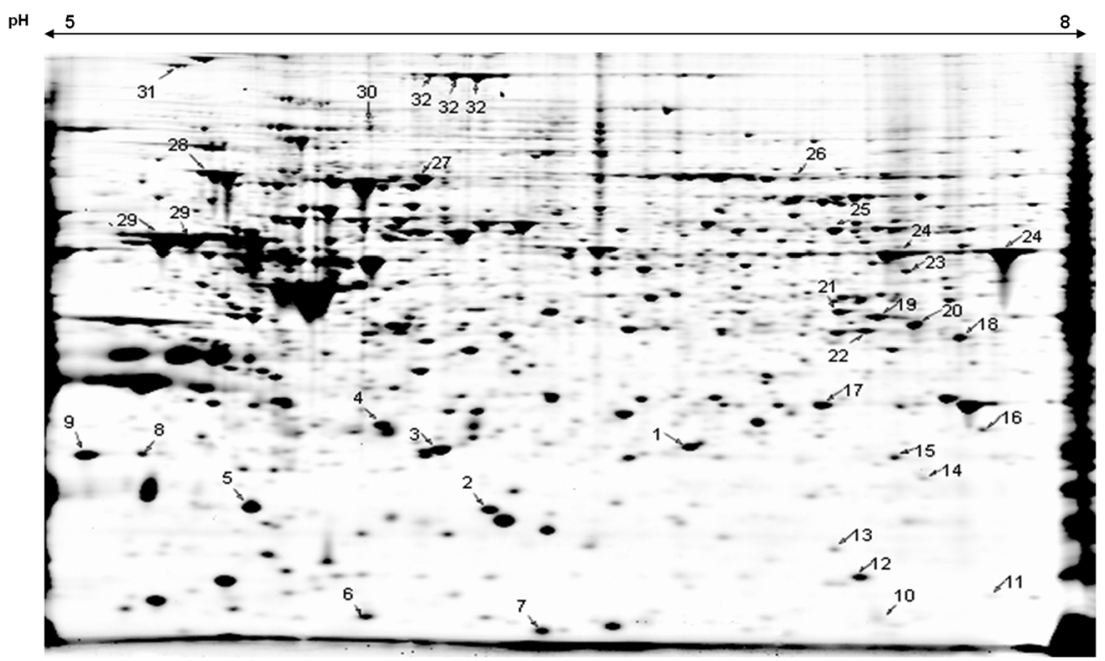

Fig. 4 2-DE protein map of total proteins isolated from control and treated cells. $150 \mu \mathrm{g}$ proteins were loaded on an $11 \mathrm{~cm} \mathrm{IPG} \mathrm{strip} \mathrm{with} \mathrm{a} \mathrm{linear}$ pH 5-8 gradient for isoelectric focusing, and a 12\% SDS polyacrylamide gel was used for SDS-PAGE. Proteins were stained with flamingo. Selected proteins, that were found to be differently expressed in both groups, were assigned a number corresponding to their number in Table 1 . 

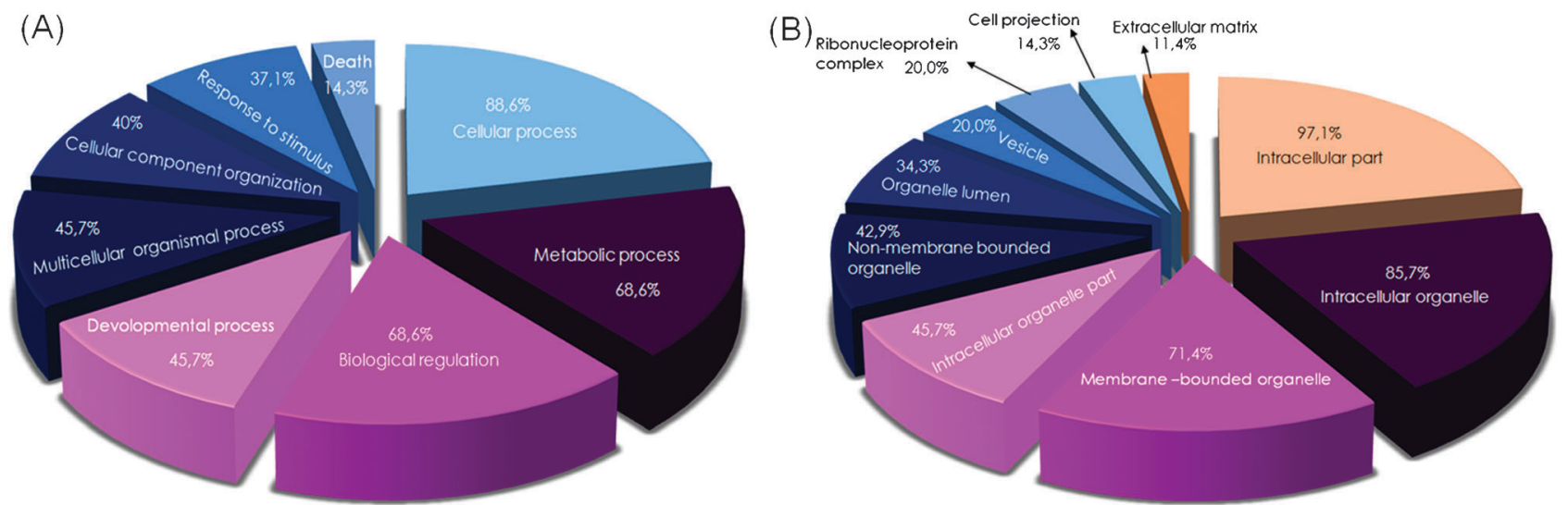

Fig. 5 Assignment of identified proteins into groups using DAVID Bioinformatics database resource. The list of genes to be analyzed was uploaded into Gene list Manager Window and Homo sapiens was chosen as the background. The gene list was then submitted for DAVID conversion tool. Based on the corresponding DAVID gene IDs and thresholds adjustment (Max-Prob $\leq 0.1$ and Min Count $\geq 2$ ) in Chart Option section, functional annotations associated with each gene were displayed in a chart. (A) GO analysis of molecular functions. (B) GO analysis of sub cellular locations. Both analyses are represented as pie charts showing the different categories.

organelle lumen, vesicle, ribonucleoprotein complex, cell projection and extracellular matrix (Fig. 5B).

For quantitative evaluation of the amount of some oxidative stress-related proteins namely, PARK7, SOD1, PRDX6, VIM, VCL and FN1, the difference in spot volume for each protein was analyzed using the DECODON and Graph Pad Prism 4 software. Fig. 6A represents enlarged gel sections of parallel gel runs for the control and the treated cell groups pointing to the protein in concern. The expression quantification of each specific protein is presented in Fig. $6 \mathrm{~B}$ as a grouped bar chart with error bars. Each bar represents the volume means $\pm \mathrm{SD}$ of gels from three independent experiments. In addition to their significant up-regulation in response to oxidative injury, PARK7 and SOD1 were also observed to acquire a different $\mathrm{pI}$ value (Fig. 6A).

\section{Western blot analysis}

In order to highlight the protein expression changes after oxidative stress and to verify the data from proteomic analysis, Western-blot analysis was performed using specific antibodies. Spot intensities were quantified using the Image $\mathbf{J}$ and Graph

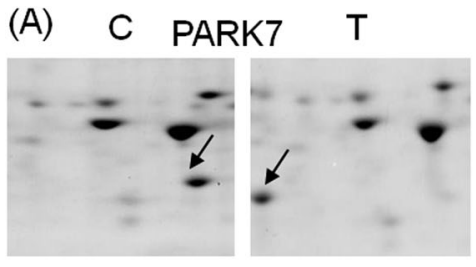

PRDX6

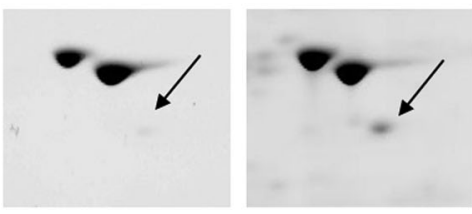

VCL
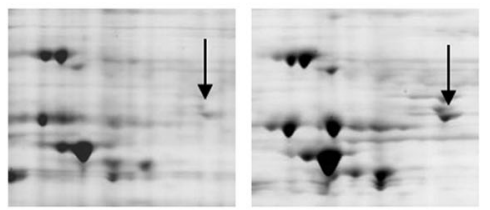

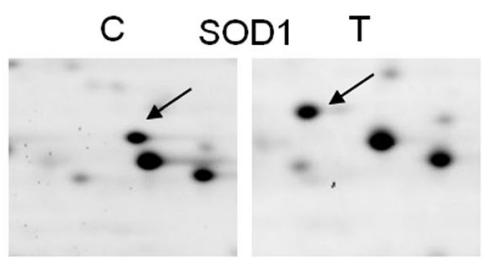

(B)
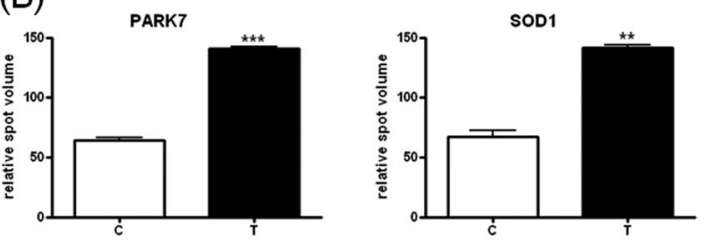

VIM
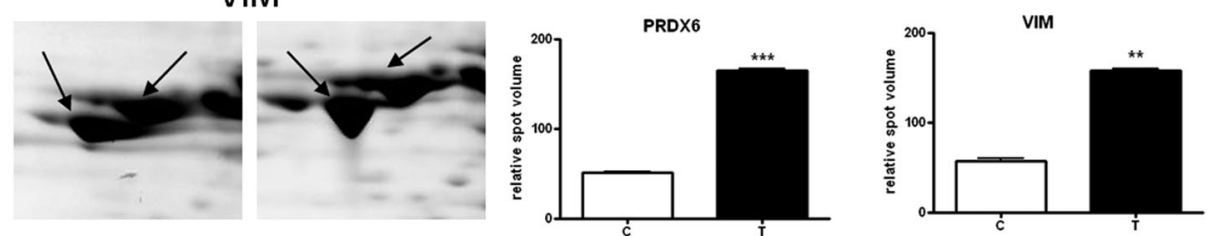

FN1
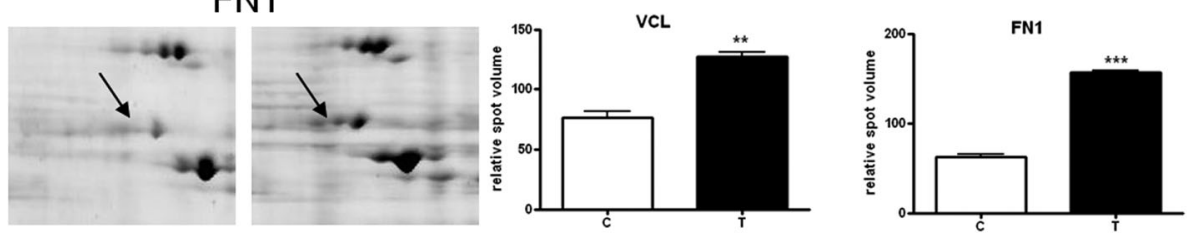

Fig. 6 (A) Graphs represent enlargement of the gel regions of interest showing protein spots found to be differentially expressed in the $\mathrm{H}_{2} \mathrm{O}_{2}$ treated (T) group of cells compared to their respective control (C). (B) The protein expression quantification for the selected proteins is given in the form of bar diagrams. On the $y$-axis the relative volume of spot, on the $x$-axis the corresponding gene name. Labeling of the graph boxes corresponds to control and treated cells. Results are given as the means $\pm \mathrm{SD}$ of the percentage volume of spots from at least three independent experiments. $* * P<0.01, * * * P<0.001$. 
(A)

PARK7

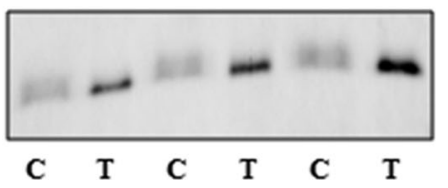

PRDX

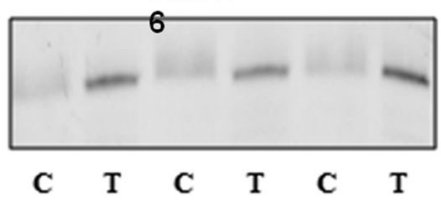

SOD1

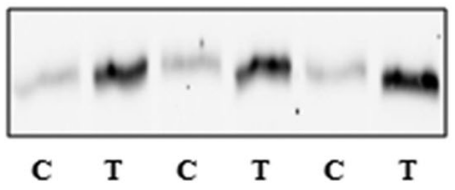

VIM

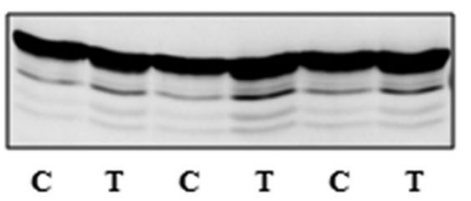

(B)
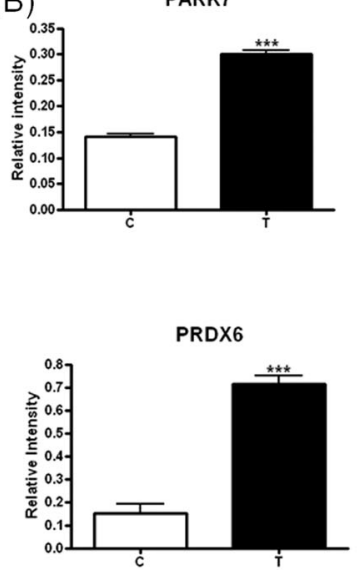

vcL

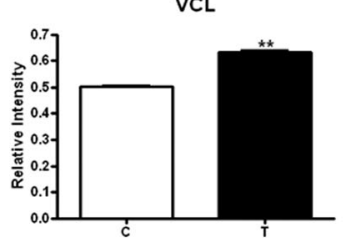

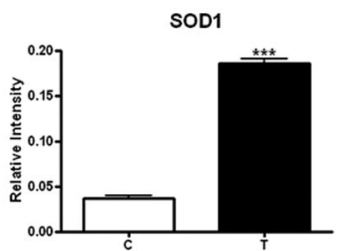

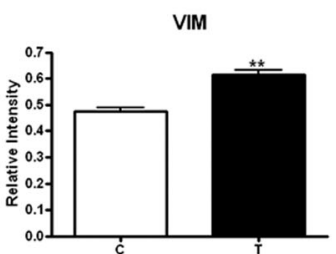

FN1

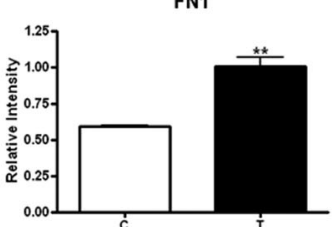

ACTB

Fig. 7 Western blot analysis of selection of proteins found to be up-regulated. Control (C) and treated (T) samples were tested for protein expression changes against the appropriate proteins. A: blots probed with antibodies against the appropriate proteins. B: blots quantification. The degree of differential protein expression is shown in the histogram. The expression quantification is presented as a grouped bar chart with error bars. Each bar represents the intensity means $\pm \mathrm{SD}$ of blots from three independent experiments. ${ }^{* *} P<0.01,{ }^{* * *} P<0.001$.

Pad Prism 4 software. Histograms depict comparative levels of the specific protein expression. Consistent with 2-DE data, oxidative stress marker proteins (PARK7, SOD1 and PRDX6) were significantly up-regulated after $\mathrm{H}_{2} \mathrm{O}_{2}$ stimulation compared with the corresponding untreated controls (Fig. 7A and B). In addition to these proteins certain fibrosis marker proteins (VIM, VCL, and FN1) were also significantly over-expressed under $\mathrm{H}_{2} \mathrm{O}_{2}$ treatment compared to the controls when $\beta$-actin was kept as standard (Fig. 7A and B).

\section{PARK7 plays an important role in oxidative stress resistance of renal cells}

To assess whether PARK7 plays an important role in kidney cells under oxidative stress, we performed knockdown experiments in the human fibroblast kidney cell line TK173. Western blot analysis showed a $>90 \%$ efficiency in the reduction of endogenous PARK7 protein levels, when $\beta$-actin was kept as standard (Fig. 8A). Interestingly, knockdown of PARK7 also led to a significantly reduced viability of TK173 under oxidative stress conditions. MTT assay revealed that the viability of PARK7 knockdown cells compared to both controls (untransfected and transfected with empty plasmid) was decreased by more than $80 \%$ upon treatment with $\mathrm{H}_{2} \mathrm{O}_{2}$ (Fig. 8B). In addition, morphological evaluation by microscopy showed that PARK7 knockdown had no significant effect on cell morphology under normal conditions, whereas the reduced level of PARK7 expression caused marked changes in morphological characters finally leading to cell death upon treatment with $\mathrm{H}_{2} \mathrm{O}_{2}$ in comparison to controls (Fig. 8C).

To further evaluate the role of PARK 7 in oxidative stress in renal cells, we suppressed the PARK7 expression with siRNA vector transfection in renal tubular cell line HK-2. Western blot of HK-2 cells transfected with PARK7 siRNA showed a significantly reduced expression of PARK 7 of $>60 \%$ compared to their untreated controls with $\beta$-actin as internal standard (Fig. 9A and B). Moreover, cell viability assay showed a highly significant decrease in cell viability in PARK7 knockdown cells treated with different concentrations of $\mathrm{H}_{2} \mathrm{O}_{2}$ (Fig. 9C). These findings suggest that the knockdown of PARK7 compromised the oxidative stress resistance not only of the TK173 cells but also of HK-2 cells.

\section{Discussion}

The observations reported in the present work provide evidence for the injury potential of $\mathrm{H}_{2} \mathrm{O}_{2}$ as a stress mediator to renal fibroblastic and epithelial cells. $\mathrm{H}_{2} \mathrm{O}_{2}$ caused cell death after $24 \mathrm{~h}$ in a concentration dependent manner. Yanagida and co-workers ${ }^{6}$ observed similar effects of $\mathrm{H}_{2} \mathrm{O}_{2}$ using human neuroblastoma cells. Treatment of cells with lower $\mathrm{H}_{2} \mathrm{O}_{2}$ concentrations, in the present work, was sufficient to evoke oxidative stress and affect cell viability. The rate of decline in 


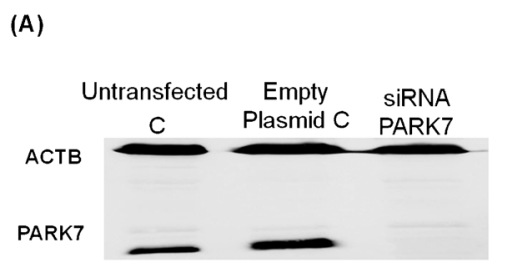

(B)
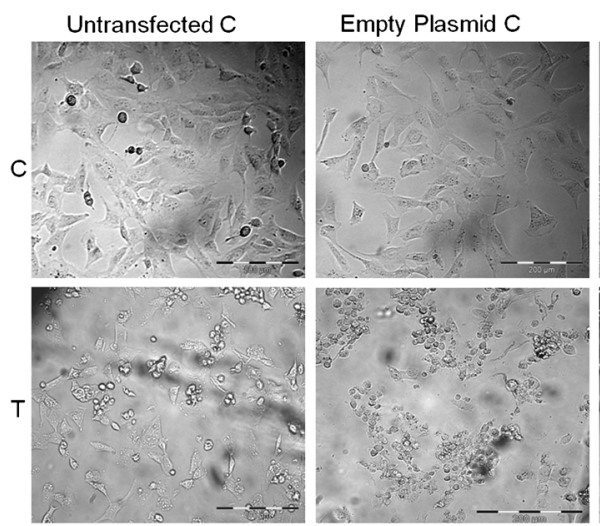

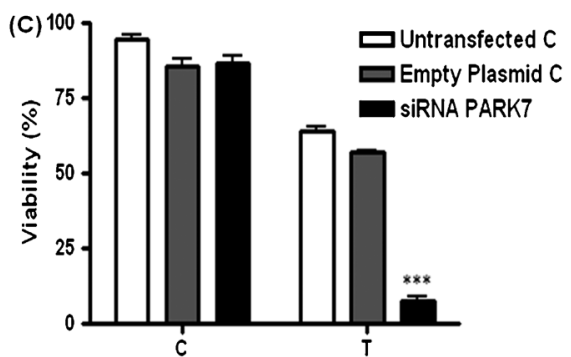

SIRNA PARK7
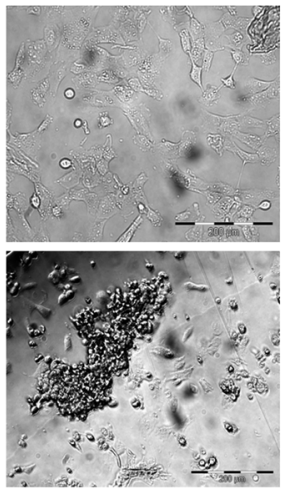

Fig. 8 (A) Expression of PARK 7 in TK173 untransfected, with empty plasmid transfected and siRNA PARK7 transfected cells. A representative Western blot with anti-PARK 7 antibody showing expression levels in TK173 cells (untransfected), in cells transfected with empty plasmid only and in cells transfected with siRNA vector targeting PARK7 (siRNA PARK7). Almost 100\% knockdown of PARK7 was achieved in siRNA PARK7 transfected cells. (B) The morphological changes induced by PARK7 knockdown and $\mathrm{H}_{2} \mathrm{O}_{2}$ exposure on TK173 cells. Morphological examination conducted after $24 \mathrm{~h}$ exposure to $\mathrm{H}_{2} \mathrm{O}_{2}$ : the cell growth was dramatically inhibited in the siRNA PARK7 transfected cells, these became irregular shapes and show high apoptosis reflected in increased floating cells (scale bar $=100 \mu \mathrm{m}$ ). (C) MTT assay results comparing the percent viability of the siRNA PARK7 to control set groups, untransfected and with empty plasmid transfected TK173 under normal and treated conditions. Results are represented as a mean of 12 readings $\pm \mathrm{SD}$. ${ }^{* *} P<0.01, * * * P<0.001$.

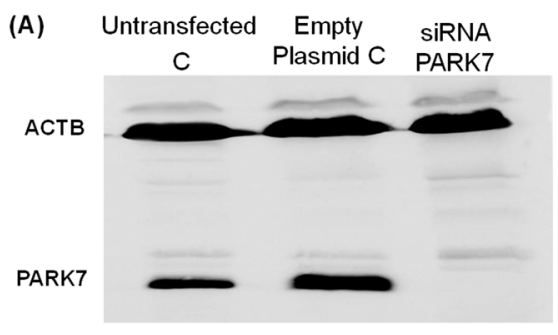

(C)

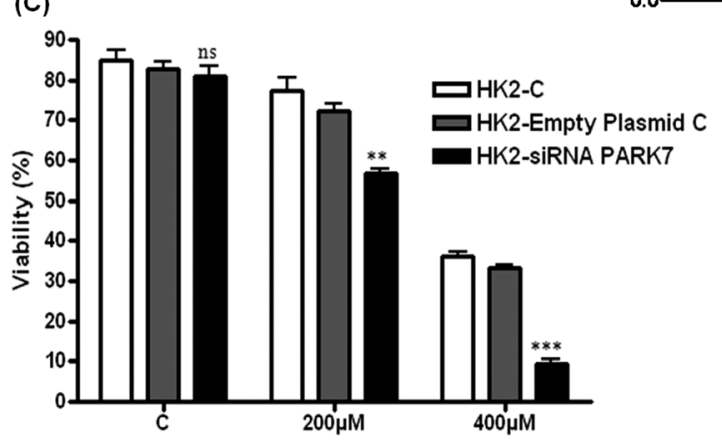

(B)

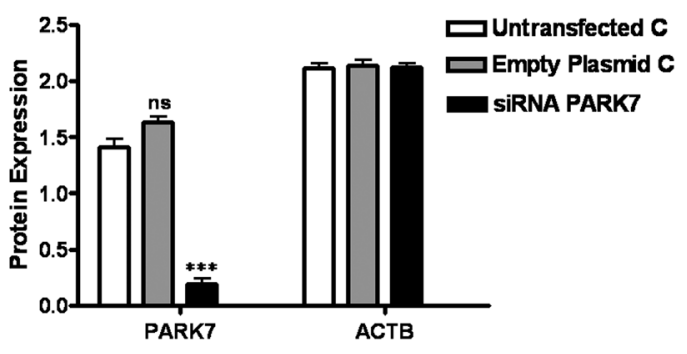

Fig. 9 (A) Western blot analysis for the efficiency of PARK7 knockdown at protein levels in renal epithelial cells after siRNA vector transfection: siRNA PARK 7 transfected HK-2 cells were compared to untransfected controls and to cells transfected with empty plasmid, $\beta$-actin was kept as standard. (B) Quantification of Western blot: The degree of differential protein expression is shown in the histogram. The expression quantification is presented as a grouped bar chart with error bars. Each bar represents the intensity means \pm SD of blots from three independent experiments. ${ }^{* *} P<0.01,{ }^{* * *} P<0.001$. (C) MTT assay results comparing the percent viability of the siRNA PARK7 transfected HK-2 cells to control under normal and treated conditions. Results are represented as a mean of 12 readings $\pm \mathrm{SD}$. ${ }^{* *} P<0.01,{ }^{* * *} P<0.001$. 
cell number was not only concentration but also time dependent. Similarly Andreucci et al. ${ }^{28}$ demonstrated that short time incubation of human renal proximal tubular cells (HK-2) with $\mathrm{H}_{2} \mathrm{O}_{2}$ resulted in a significant decrease in cell viability. ${ }^{28}$ Moreover, in a recent comparison of the same cells with the renal distal tubular cells (MCDK) demonstrated that apoptosis, loss of cell adhesion and cell death were more obvious in the HK-2 cell line after application of the same stress mediator. ${ }^{29}$ These observations indicate that $\mathrm{H}_{2} \mathrm{O}_{2}$ as the oxidative stress agent dramatically impacts the renal cells. However the exact molecular mechanisms underlying the effect of $\mathrm{H}_{2} \mathrm{O}_{2}$ on cell viability and survival and the mechanisms involved in antioxidant defenses are still not completely understood. Hence, there is compelling need to elucidate the molecular mechanisms associated with the subtle lesions caused by $\mathrm{H}_{2} \mathrm{O}_{2}$ that eventually may be of major consequence in the development of renal fibrosis. Our proteomic signatures powerfully explored global changes with respect to regulation and expression of stress responsive proteins in TK173 cells after exposure to $\mathrm{H}_{2} \mathrm{O}_{2}$ stress. Using 2D-gel electrophoresis and mass spectrometry numerous proteins showed high expression in response to $\mathrm{H}_{2} \mathrm{O}_{2}$ treatment.

As reaction on the oxidative insult, renal cells reacted with alteration in the expression of large number of oxidative stress, cytoskeleton and fibrosis marker proteins. Oxidative stress proteins include peroxiredoxins (PRDXs). These are a ubiquitous family of antioxidant enzymes. As redox regulators, they appear to play a key role in homeostatic cellular survival processes; consequently, the changes in the status of these proteins in the cell can alter significantly the cellular responses to various stimuli. The important physiological functions of PRDXs are emphasized by the wide tissue expression of the corresponding family members. In fact, a major common function of PRDXs is the enzymatic degradation of $\mathrm{H}_{2} \mathrm{O}_{2} \cdot{ }^{30}$ Multiple mammalian PRDXs (I through VI) often coexist in the same cell in various intracellular locations and function as scavengers of endogenous $\mathrm{H}_{2} \mathrm{O}_{2}$ free radicals released after stimulation with growth factors during proliferation, apoptosis or oxidative stress. ${ }^{31}$ This is in consistence with our observation of an alteration in different PRDXs detected in our 2D electrophoresis. Especially PRDX6 was significantly increased in renal cells subjected to oxidative stress using $\mathrm{H}_{2} \mathrm{O}_{2}$. PRDX6 was found to be expressed in all major mammalian organs. ${ }^{32}$ PRDX6 knockout mice were observed to have lower survival rates, as well as higher protein oxidation levels with more severe tissue damage in organs such as kidney, liver and lung. ${ }^{33}$ Over-expression of PRDX6 as a fusion construct with green fluorescent protein in $\mathrm{H} 441$ cells, an epithelial cell line that does not express PRDX6, protected this cell against $\mathrm{H}_{2} \mathrm{O}_{2}$. Over-expressing cells showed less lipid peroxidation and decreased damage to cellular plasma membranes. ${ }^{34}$ Our data confirmed previous observations, where PRDX6 was qup-regulated in $\mathrm{H}_{2} \mathrm{O}_{2}$-induced cells and acted in antioxidant defense by facilitating repair of damaged cells.

Beside PRDXs other oxidative stress proteins like superoxide dismutases (SODs) were found to be up-regulated. SODs are metalloenzymes that have been described to exist in humans in three forms with distinctive cellular distribution and metal requirements. Particularly SODs as further antioxidants have clearly proven to be effective both in terms of inhibiting and in reversing established fibrosis. ${ }^{35}$ Under normal circumstances, the free radicals burden is controlled by SOD enzymes in the mitochondria (homotetrameric Mn-based) ${ }^{36}$ or in the cytosol (homodimetric $\mathrm{Cu} / \mathrm{Zn}$ ). ${ }^{37} \mathrm{The}$ development of nonpeptidyl SOD mimics, ${ }^{38}$ and of $\mathrm{H}_{2} \mathrm{O}_{2}$ scavengers that influence profibrogenic mediators expression ${ }^{39}$ offer promise of improved clinical therapies for ROS-mediated injury. The abundant expression of $\mathrm{Cu} / \mathrm{Zn} \mathrm{SOD}$ together with the pI shift acquired in our $\mathrm{H}_{2} \mathrm{O}_{2}$ stressed cells may have important effect on the diverse functions of this protein as an antioxidant. The data demonstrate that the stressed cells react with increased expression of antioxidant enzymes. These results are in harmony with previously reported elevated expression of $\mathrm{Cu} / \mathrm{Zn}$ SOD in $\mathrm{H}_{2} \mathrm{O}_{2}$ resistant Chinese hamster fibroblasts. ${ }^{40,41}$

As part of oxidative stress response renal cells increased the expression of PARK7, a protein originally discovered as an oncogene, ${ }^{18}$ was later found to be responsible for the early onset of Parkinson's disease, ${ }^{42}$ to be related to infertility ${ }^{43}$ besides its over-expression in multiple tumors. ${ }^{44}$ It was also identified as a hydroperoxide-responsive protein. ${ }^{6}$ However, the molecular mechanism by which PARK7 exerts these multiple functions remains elusive. Several lines of evidence support a protective role of PARK7 against oxidative stress. Our proteomic analysis extended the above cited investigations and revealed that upon oxidative stress, PARK7 was significantly highly up-regulated and that its $\mathrm{pI}$ was shifted to a more acidic point suggesting that PARK7 was oxidized and consequently modified to acquire a slightly lower $\mathrm{pI}$. Conversion of PARK7 into a pI variant in response to $\mathrm{H}_{2} \mathrm{O}_{2}$ had already been reported. ${ }^{6,44,45}$ In neuroblastoma cells, PARK7 eliminated $\mathrm{H}_{2} \mathrm{O}_{2}$ by oxidizing itself. The PARK7 oxidation and subsequent activation was a prerequisite for protection of cells against $\mathrm{H}_{2} \mathrm{O}_{2}$-induced cell death. ${ }^{46}$ The PARK7 protein induced an immediate antioxidant response by direct trapping of oxygen atoms, oxidizing its cysteine 106 residue and thus quenching reactive oxygen species. ${ }^{6}$ PARK 7 also induced an indirect response, which was mediated through the stabilization of the nuclear erythroid 2 related factor (Nrf2) which resulted in the activation of antioxidant transcriptional responses. ${ }^{47}$ Considering the structural similarity of PARK 7 and the GAT superfamily proteins, PARK7 appeared to sense oxidative stress and to gain the protease activity for the digestion of oxidative damaged proteins. ${ }^{48}$ Furthermore, in addition to its presence in the cytoplasm, mitochondria, and nucleus, PARK7 protein has been also detected in extracellular spaces $^{49}$ suggesting that it may function both intracellular and extracellular. In 2008, Lev et al. ${ }^{50}$ demonstrated that over-expression of PARK7 in human neuroblastoma cells resulted in increased cellular resistance to $\mathrm{H}_{2} \mathrm{O}_{2}$ and reduced intra-cellular ROS, whereas contrary effects were achieved when PARK 7 levels were reduced by siRNA. Using a similar cell model Yanagida et al. ${ }^{6}$ showed that even a low $\mathrm{H}_{2} \mathrm{O}_{2}$ concentration induced a significant intracellular ROS production and cell death in PARK7 knockdown cells, while this was only slightly induced in normal cells. The effect of oxidative stress on PARK 7 in renal cells and the fact that PARK7 knockdown rendered renal cells more susceptible to oxidative stress 
confirm the pivotal role of PARK7 also in renal cell resistance to oxidative stress and possibly in renal fibrosis.

Parallel to up-regulation of the oxidative stress marker and subsequent activation of antioxidant defense, the renal cells showed an over-expression of cytoskeleton and fibrosis marker proteins indicating potential cell transformation under $\mathrm{H}_{2} \mathrm{O}_{2}$ treatment. Fibrosis markers e.g. FN1 and COLIA1 were up-regulated under $\mathrm{H}_{2} \mathrm{O}_{2}$ treatment confirming the pro-fibrotic effect of oxidative stress. Evidence exists linking overexpression of extracellular matrix components such as FN1 and COLIA1 with tubulointerstitial fibrosis. ${ }^{51,52}$ As a direct effect of $\mathrm{H}_{2} \mathrm{O}_{2}$, also messenger levels of FN1 were found to be increased in human mesengial cells, suggesting that $\mathrm{H}_{2} \mathrm{O}_{2}$ may have stimulated ECM proteins expression by a direct effect or an indirect effect through activation of the TGF- $\beta$ system. ${ }^{53}$ Similarly, accompanying ROS increase in renal cells, vimentin and vinculin as components and interacting molecules of cytoskeleton were found to be up-regulated after oxidative stress, indicating a role of these proteins in stress protection. The present finding, together with the observation that cytoskeleton proteins ${ }^{10,54}$ were also up-regulated in response to oxidative stimuli in other cell systems, strengthens the hypothesis of a protective role of the cytoskeleton as part of the cellular response to oxidative stress. ${ }^{55}$

In conclusion, the up-regulation of the overviewed proteins in renal cells under oxidative stress conditions, in the present work, was found to be a major cellular recovery response after oxidative damage. The proteins identified in the context of renal cell and oxidative stress may provide a new clue on the molecular events leading to cell transformation and renal fibrosis. The regulation of these proteins may present a chief target for protective therapeutic interventions. We further demonstrate the important role of PARK7 in renal cells exposed to an environment that promotes the formation of intracellular ROS. Our data further prove that proteomic techniques can be valuable tools in the study of protein profiling modifications during oxidative stress.

\section{References}

1 B. Halliwell, Biochem. Pharmacol., 1995, 49, 1341-1348.

2 M. B. Hampton and S. Orrenius, FEBS Lett., 1997, 414, $552-556$.

3 S. M. Son, Diabetes Res. Clin. Pract., 2007, 77(Suppl 1), S65-S70.

4 T. D. Oberley, Am. J. Pathol., 2002, 160, 403-408.

5 A. Gella and N. Durany, Cell Adhes. Migr., 2009, 3, 88-93.

6 T. Yanagida, Y. Kitamura, K. Yamane, K. Takahashi, K. Takata, D. Yanagisawa, H. Yasui, T. Taniguchi, T. Taira, T. Honda and H. Ariga, J. Pharmacol. Sci., 2009, 109, 463-468.

7 N. Kemal Duru, M. Morshedi and S. Oehninger, Fertil. Steril., 2000, 74, 1200-1207.

8 L. Cesaratto, C. Vascotto, C. D'Ambrosio, A. Scaloni, U. Baccarani, I. Paron, G. Damante, S. Calligaris, F. Quadrifoglio, C. Tiribelli and G. Tell, Free Radical Res., 2005, 39, 255-268.

9 T. E. Cullingford, R. Wait, A. Clerk and P. H. Sugden, J. Mol. Cell. Cardiol., 2006, 40, 157-172.

10 S. Goswami, N. L. Sheets, J. Zavadil, B. K. Chauhan, E. P. Bottinger, V. N. Reddy, M. Kantorow and A. Cvekl, Invest. Ophthalmol. Visual Sci., 2003, 44, 2084-2093.

11 A. Thomson, D. Hemphill and K. N. Jeejeebhoy, Dig. Dis., 1998, 16, $152-158$.

12 J. Kim, Y. M. Seok, K. J. Jung and K. M. Park, Am. J. Physiol.: Renal Physiol., 2009, 297, F461-F470.
13 J. Chandra, A. Samali and S. Orrenius, Free Radical Biol. Med., 2000, 29, 323-333.

14 V. Chavez, A. Mohri-Shiomi, A. Maadani, L. A. Vega and D. A. Garsin, Genetics, 2007, 176, 1567-1577.

15 R. Doonan, J. J. McElwee, F. Matthijssens, G. A. Walker, K. Houthoofd, P. Back, A. Matscheski, J. R. Vanfleteren and D. Gems, Genes Dev., 2008, 22, 3236-3241.

16 J. M. Van Raamsdonk and S. Hekimi, PLoS Genet., 2009, 5, e1000361.

17 K. Yen, H. B. Patel, A. L. Lublin and C. V. Mobbs, Mech. Ageing Dev., 2009, 130, 173-178.

18 D. Nagakubo, T. Taira, H. Kitaura, M. Ikeda, K. Tamai, S. M. Iguchi-Ariga and H. Ariga, Biochem. Biophys. Res. Commun., 1997, 231, 509-513.

19 P. J. Kahle, J. Waak and T. Gasser, Free Radical Biol. Med., 2009, 47, 1354-1361.

20 K. Nomura, H. Imai, T. Koumura and Y. Nakagawa, Biol. Signals Recept., 2001, 10, 81-92.

21 G. A. Muller, J. Frank, H. P. Rodemann and G. Engler-Blum, Exp. Nephrol., 1995, 3, 127-133.

22 M. J. Ryan, G. Johnson, J. Kirk, S. M. Fuerstenberg, R. A. Zager and B. Torok-Storb, Kidney Int., 1994, 45, 48-57.

23 M. V. Berridge and A. S. Tan, Arch. Biochem. Biophys., 1993, 303, 474-482.

24 L. M. Henderson and J. B. Chappell, Eur. J. Biochem., 1993, 217, 973-980.

25 M. M. Bradford, Anal. Biochem., 1976, 72, 248-254.

26 H. Dihazi, A. R. Asif, N. K. Agarwal, Y. Doncheva and G. A. Muller, Mol. Cell. Proteomics, 2005, 4, 1445-1458.

27 H. Towbin, T. Staehelin and J. Gordon, Proc. Natl. Acad. Sci. U. S. A., 1979, 76, 4350-4354.

28 M. Andreucci, G. Fuiano, P. Presta, G. Lucisano, F. Leone, L. Fuiano, V. Bisesti, P. Esposito, D. Russo, B. Memoli, T. Faga and A. Michael, Cell Proliferation, 2009, 42, 554-561.

29 C. J. Percy, B. K. Pat, H. Healy, D. W. Johnson and G. C. Gobe, Pathology, 2008, 40, 694-701.

30 Z. A. Wood, L. B. Poole and P. A. Karplus, Science, 2003, 300, $650-653$

31 S. W. Kang, H. Z. Chae, M. S. Seo, K. Kim, I. C. Baines and S. G. Rhee, J. Biol. Chem., 1998, 273, 6297-6302.

32 G. Leyens, I. Donnay and B. Knoops, Comp. Biochem. Physiol., Part B: Biochem. Mol. Biol., 2003, 136, 943-955.

33 X. Wang, S. A. Phelan, K. Forsman-Semb, E. F. Taylor, C. Petros, A. Brown, C. P. Lerner and B. Paigen, J. Biol. Chem., 2003, 278, 25179-25190.

34 Y. Manevich, T. Sweitzer, J. H. Pak, S. I. Feinstein, V. Muzykantov and A. B. Fisher, Proc. Natl. Acad. Sci. U. S. A., 2002, 99, 11599-11604.

35 J. L. Lefaix, S. Delanian, J. J. Leplat, Y. Tricaud, M. Martin, A. Nimrod, F. Baillet and F. Daburon, Int. J. Radiat. Oncol., Biol., Phys., 1996, 35, 305-312.

36 S. L. Marklund, Proc. Natl. Acad. Sci. U. S. A., 1982, 79, 7634-7638.

37 J. M. McCord and I. Fridovich, J. Biol. Chem., 1969, 244, 6049-6055.

38 D. Salvemini, Z. Q. Wang, J. L. Zweier, A. Samouilov, H. Macarthur, T. P. Misko, M. G. Currie, S. Cuzzocrea, J. A. Sikorski and D. P. Riley, Science, 1999, 286, 304-306.

39 W. Zhao, D. R. Spitz, L. W. Oberley and M. E. Robbins, Cancer Res., 2001, 61, 5537-5543.

40 J. A. Keightley, L. Shang and M. Kinter, Mol. Cell. Proteomics, 2004, 3, 167-175.

41 D. R. Spitz, J. H. Elwell, Y. Sun, L. W. Oberley, T. D. Oberley, S. J. Sullivan and R. J. Roberts, Arch. Biochem. Biophys., 1990, 279, 249-260.

42 V. Bonifati, P. Rizzu, M. J. van Baren, O. Schaap, G. J. Breedveld, E. Krieger, M. C. Dekker, F. Squitieri, P. Ibanez, M. Joosse, J. W. van Dongen, N. Vanacore, J. C. van Swieten, A. Brice, G. Meco, C. M. van Duijn, B. A. Oostra and P. Heutink, Science, 2003, 299, 256-259.

43 M. Okada, K. Matsumoto, T. Niki, T. Taira, S. M. Iguchi-Ariga and H. Ariga, Biol. Pharm. Bull., 2002, 25, 853-856.

44 J. E. Tillman, J. Yuan, G. Gu, L. Fazli, R. Ghosh, A. S. Flynt, M. Gleave, P. S. Rennie and S. Kasper, Cancer Res., 2007, 67, $4630-4637$. 
45 A. Mitsumoto, Y. Nakagawa, A. Takeuchi, K. Okawa, A. Iwamatsu and Y. Takanezawa, Free Radical Res., 2001, 35, 301-310.

46 P. Jenner, Ann. Neurol., 2003, 53(Suppl 3), S26-S36.

47 C. M. Clements, R. S. McNally, B. J. Conti, T. W. Mak and J. P. Ting, Proc. Natl. Acad. Sci. U. S. A., 2006, 103, 15091-15096.

48 K. Honbou, N. N. Suzuki, M. Horiuchi, T. Niki, T. Taira,

H. Ariga and F. Inagaki, J. Biol. Chem., 2003, 278, 31380-31384.

49 M. Waragai, J. Wei, M. Fujita, M. Nakai, G. J. Ho, E. Masliah, H. Akatsu, T. Yamada and M. Hashimoto, Biochem. Biophys. Res. Commun., 2006, 345, 967-972.
50 N. Lev, D. Ickowicz, E. Melamed and D. Offen, NeuroToxicology, 2008, 29, 397-405.

51 A. A. Eddy, J. Am. Soc. Nephrol., 1996, 7, 2495-2508.

52 F. Strutz, Nephrol., Dial., Transplant., 1995, 10, 1526-1532.

53 F. Strutz, M. Zeisberg, A. Renziehausen, B. Raschke, V. Becker, C. van Kooten and G. Muller, Kidney Int., 2001, 59, 579-592.

54 M. R. Clarkson, M. Murphy, S. Gupta, T. Lambe, H. S. Mackenzie, C. Godson, F. Martin and H. R. Brady, J. Biol. Chem., 2002, 277, 9707-9712.

55 S. M. Liu and T. Sundqvist, Exp. Cell Res., 1995, 217, 1-7. 